\title{
Antitumor activity of Actinobacteria isolated in marine sediment from Todos Santos Bay, Baja California, Mexico
}

Actividad antitumoral de Actinobacterias aisladas de sedimento marino de la Bahía de Todos Santos, Baja California, México

\section{Amayaly Becerril-Espinosa ${ }^{1}$, Graciela Guerra-Rivas ${ }^{1}$, Nahara Ayala-Sánchez ${ }^{2}$ and Irma E. Soria-Mercado ${ }^{1}$}

\begin{abstract}
${ }^{1}$ Facultad de Ciencias Marinas, Universidad Autónoma de Baja California, km 103 Carretera Tijuana-Ensenada, Baja California, México. iesoria@uabc.edu.mx

${ }^{2}$ Facultad de Ciencias, Universidad Autónoma de Baja California, km 103 Carretera Tijuana-Ensenada, Baja California, México
\end{abstract}

Resumen.- Se realizó el estudio de la bioactividad de las Actinobacterias cultivables a partir de sedimento marino de la Bahía de Todos Santos, México, y se identificaron mediante las secuencias del gen 16S ARNr. Las cepas bacterianas fueron cultivadas en $1 \mathrm{~L}$ de medio líquido A1 y se constató su crecimiento en presencia de agua de mar. Los extractos orgánicos de los cultivos se extrajeron con Amberlita XAD-7 eluida con acetona. Los extractos fueron separados por cromatografía en gel de sílice C-18. Los extractos crudos y las fracciones se probaron contra células de cáncer de colon HCT-116. En total, 26 cepas fueron cultivadas e identificadas, divididas en 10 unidades taxonómicas operacionales (UTOs) con 100\% de identidad de sus secuencias, representando tres familias del orden Actinomycetales, pertenecientes a los géneros Streptomyces (77\%), Micromonospora (20\%) y Nocardia (3\%); 6 de éstos UTOs no habían sido reportados previamente. Diecinueve por ciento de los extractos crudos del género Streptomyces mostraron actividad citotóxica en un rango de $\mathrm{IC}_{50}$ de $69,0 \mathrm{a} \leq 0,076 \mu \mathrm{g} \cdot \mathrm{ml}^{-1}$. Las fracciones más activas contenían los compuestos monactin y derivados de pamamicina, los cuales fueron identificados por su peso molecular y sus patrones de fragmentación.

Palabras clave: Bacterias marinas, actividad antitumoral, diversidad bacteriana, filogenia

Abstract.-The bioactivity of culturable Actinobacteria from marine sediment of the Todos Santos Bay, Mexico was studied, and bacteria were identified by $16 \mathrm{~S}$ rRNA gene sequences. The strains were cultured in $1 \mathrm{~L}$ of culture media $\mathrm{A} 1$ and tested for the effects of seawater on growth. The organic components of cultures were extracted with XAD-7 amberlite and eluted with acetone. The extracts were separated by flash chromatography on C-18 silica gel. The crude extracts and the fractions were tested against colorectal cancer cells HCT-116. In total, twenty six strains were cultured and identified, divided into ten operational taxonomic units (OTUs) with $100 \%$ sequence identity, representing 3 families in the order Actinomycetales, belonging to the genus Streptomyces (77\%), Micromonospora (20\%) and Nocardia (3\%); six of those OTUs had not been reported before. Nineteen percent of the crude extracts of the Streptomyces genus showed cytotoxic activity in a range of $\mathrm{IC}_{50}$ of 69.0 to $\leq 0.076 \mu \mathrm{g} \cdot \mathrm{ml}^{-1}$. The most active fractions contained compounds identified by their molecular weight and fragmentation patterns as monactin and pamamycin derivatives.

Key words: Marine bacteria, antitumor activity, bacterial diversity, phylogeny

\section{INTRODUCTION}

Actinobacteria are broadly studied due to their capability of producing a great variety of chemical compounds with medical importance and high commercial value for the pharmaceutical industry. About $70 \%$ of the bioactive secondary metabolites reported are produced by these microorganisms. The Streptomyces genus has been widely studied over the last sixty years and it is the source of more than 7,600 compounds including antitumor drugs (Bérdy 2005). 
The Actinobacteria that produce bioactive metabolites have been isolated mainly from terrestrial environments. Compounds of this bacteria are producers of medicines, e.g., streptomycin the first compound used as a treatment for tuberculosis. Other drugs derived originally from these microorganisms are erythromycin and tetracycline. Nevertheless, the amount of new metabolites obtained from terrestrial microorganisms has decreased considerably. For this reason, great research efforts have been made in the past decade to search for these microorganisms in the marine environment and the results have been very productive (Mincer et al. 2002, Feling et al. 2003, Maldonado et al. 2005, Jensen \& Mafnas 2006, Jensen et al. 2007). New bacterial diversity discovered in the ocean, contains species that produce new chemical compounds with antitumor activity and other pharmacological properties never seen before in terrestrial Actinobacteria (Olano et al. 2009). There is evidence that the secondary metabolites produced predominantly by these marine strains are meroterpenes, which is highly unusual for actinomycetes (Pathirana et al. 1992, Hardt et al. 2000, Jensen \& Fenical 2005, Moore et al. 2005, SoriaMercado et al. 2005).

Among Actinobacteria, the genus Salinispora is considered a strictly marine group because it requires seawater for growth. There are two species formally described in this genus: S. arenicola and S. tropica (Maldonado et al. 2005). These species produce several newly identified compounds with cytotoxic activity against different cancer cellular lines; one of these compounds is salinosporamide A, isolated from $S$. tropica, which is in clinical trials for cancer treatment (Fenical et al. 2009). Other novel Actinobacteria include the genus Marinispora (Kwon et al. 2006), which belongs to the Streptomycetaceae family and produces chemical compounds such as marinomycin A-D with potent antibacterial activity. Marinomycin A showed significant activity against human melanoma cell lines LOX IMVI, M14, SK-MEL-2, SK-MEL-5, UACC-257, and UACC-62. Marinomycins B and C also showed potent activities with $\mathrm{LC}_{50}$ values of $\mu \mathrm{M}$ range, with a specific unknown mechanism of action (Kwon et al. 2006). Actinofuranones $\mathrm{A}$ and B are two novel compounds isolated from the culture extract of a marine-derived Streptomyces strain cultured from sediments collected from Guam (Cho et al. 2006). These new compounds have a mixed polyketide/ terpenoid origin structurally related to the antibiotic A80915C (Soria-Mercado et al. 2005).
Although marine Actinobacteria are being recognized for their importance as a pharmaceutical resource, little is known about their diversity and their ecological role in the ocean. Specifically for Mexican coasts, there are few studies on bacteria, even though Mexico has a marine territory of 1,378,620 $\mathrm{km}^{2}$ of coastal and oceanic zones, which are 1.5 times the area of the terrestrial territory (De la Lanza 2004), therefore Mexican coasts provide a great research opportunity to learn more about bacterial diversity.

The aim of this research was to explore the cytotoxic activity against colorectal cancer cells HCT-116 of culturable Actinobacteria isolated from marine sediments collected from the Mexican North Pacific.

\section{MATERIALS AND METHODS}

\section{STUDY AREA}

Sediment samples were collected in Todos Santos Bay (TSB), located on the Northeast coast of Baja California (Fig. 1). The TSB area is about $240 \mathrm{~km}^{2}$ with two main entrances; the NW entrance is $12 \mathrm{~km}$ in length with an average depth less than $50 \mathrm{~m}$, and the SW entrance is 6 $\mathrm{km}$ in length with a marine canyon that reaches $400 \mathrm{~m}$ in depth. Seventy five percent of the TSB area has shallow depths of $50 \mathrm{~m}$ and the remaining 25 percent is part of the narrow submarine canyon (Sánchez et al. 2009).

\section{ACtinobacteria isolation}

Sediment samples were collected at a 15-32 m depth using a stainless steel dredge. Each sample was transferred into sterile $50 \mathrm{ml}$ plastic Whirl-Pak bags (NASCO, Modesto, $\mathrm{CA}$ ) and kept cool $\left(4^{\circ} \mathrm{C}\right)$ until processed (within $5 \mathrm{~h}$ ). Once in the laboratory the sediment was treated in two ways; first, a plate stamp technique (Mincer et al. 2002) and then serial dissolutions of 1:10, 1:100 and 1:1000 were made. These dilutions were incubated at $55^{\circ} \mathrm{C}$ for $5 \mathrm{~min}$ to enhance spore germination and improve actinomycete recovery, (Ensign 1978) and then inoculated $0.1 \mathrm{ml}$ into the media. The media used included: M1 (18 g agar, $1 \mathrm{l}$ of seawater), M2 (18 g agar, $0.5 \mathrm{~g}$ mannitol, $1 \mathrm{l}$ of seawater) and M3 [18 g agar, $1.0 \mathrm{~g}$ starch, $0.2 \mathrm{~g}$ bactopeptone, $0.4 \mathrm{~g}$ yeast extract, $1 \mathrm{l}$ of seawater, Gontang et al. (2007)]. All media were amended with cicloheximide $\left(100 \mu \mathrm{g} \cdot \mathrm{ml}^{-1}\right.$ final concentration) to reduce fungal contamination and rifamicin (5 $\mu \mathrm{g} \cdot \mathrm{ml}^{-1}$ final concentration) to select for Actinobacteria. When bacterial colonies grew (after 4-12 weeks, depending on the media) they were observed 
Figure 1. Geographic location of sampling sites at Todos Santos Bay, Ensenada, Baja California, Mexico / Localización geográfica de los sitios de muestreo en la Bahía Todos Santos, Ensenada, Baja California, México

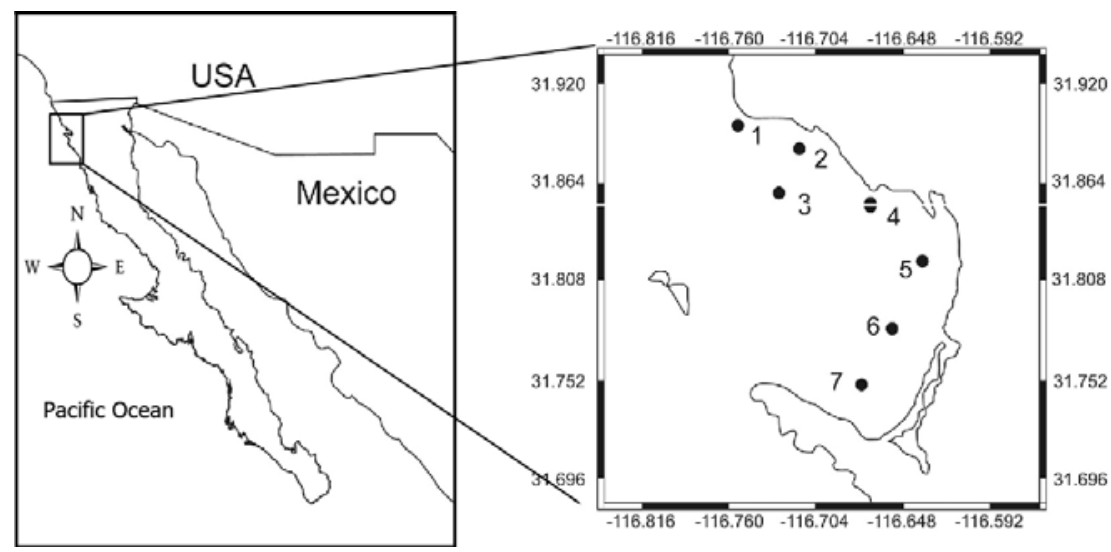

under the microscope and each colony was identified by its morphology, i.e., based on its shape and color. The filamentous bacteria that showed specific morphological characteristics of Actinobacteria were isolated and purified in culture media A1 (18 g agar, $10.0 \mathrm{~g}$ starch, $2.0 \mathrm{~g}$ bactopeptone, $4.0 \mathrm{~g}$ yeast extract, $1 \mathrm{l}$ of seawater).

The bacterial isolates were analyzed by the Gram stain following the method described by Powers (1995) and the identification of the strains with colonial morphology which differed from other isolates was done according to 16S rRNA analysis.

\section{DNA ANAlyses: PuRification AND AMPLIFICATION}

The genomic DNA of each isolate was extracted using the DNA extraction kit 'DNeasy ${ }^{\circledR}$ Blood and Tissue Kit' Cat. No. 69506 according to the protocol suggested by the manufacturer (Qiagen Corp. Ca. USA).

The 16S ribosomal DNA gene was amplified using PCR with the primers FC27 (5'-AGAGTTTGATCCTGGCTCAG3'; Galkiewicz \& Kellogg 2008) and RC1492 (5'TACGGCTACCTTGTTACGACTT-3'; Marchesi et al. 1998), under the following conditions; initial denaturalization at $95^{\circ} \mathrm{C}$ for 15 min followed by 32 cycles at $95^{\circ} \mathrm{C}$ for $1 \mathrm{~min}, 61^{\circ} \mathrm{C}$ for $1 \mathrm{~min}$ and $72^{\circ} \mathrm{C}$ for $1 \mathrm{~min}$, and a final extension at $72^{\circ} \mathrm{C}$ for $7 \mathrm{~min}$ (Gontang et al. 2007). The products were purified using the polymerase chain reaction (PCR) with the cleaner kit Qiagen QIAquick PCR, according to the protocols provided by the manufacturer (Qiagen Inc., Chatsworth, Calif.). Sequence was obtained using the primers listed above at SeqXcel, INC (http:// www.seqxcel.com/) using the BigDye Terminator Cycle Sequencing Chemistry 3.1 technique using the Genetic Analyzer ABI Prism 3100 (Applied Biosystem).

\section{Phylogenic analysis}

The 16S rRNA sequences from each isolate were compared with the available sequences at the data base BLAST (Basic Local Alignment Search Tool, Altschul et al. 1990) from the GenBank data base ${ }^{1}$. The sequences were aligned using the ClustalX program (Staley \& Ta 1985) and then imported into the Bioedit program (Hall \& Brown 2001) with manual alignment. The phylogenetic tree was constructed with the neighbor-joining algorithm with 10,000 replications using the MEGA4 program (Tamura et al. 2007) and a 707 bp segment.

\section{SEQUENCES ANALYSIS}

The Operational Taxonomic Units (OTUs) were calculated for all the partial sequences (707 bp) from 99 to $100 \%$ of the identity sequences using the Cluster program (http:/ /www.bugaco.com/mioritic/clusterer_jlp.php) to establish the distance parameter with the necessary nucleotide number to hit the target groups. Nucleotide sequence from the $16 \mathrm{~S}$ rRNA adhesion were analyzed in the GenBank under the access number HQ326147 to HQ326156 ${ }^{1}$.

\section{EFFECTS OF SEAWATER ON GROWTH}

All strains were tested for their requirement of seawater for growth. A well-defined colony of each strain was inoculated in A1 medium prepared with deionized water and seawater. Plates were incubated at $25-28^{\circ} \mathrm{C}$ and growth was monitored at up to $60 \mathrm{x}$ magnification for eight weeks; afterwards, the strains were categorized as non-seawater dependent (growth on both media) or seawater dependent (no growth on deionized water media).

${ }^{1}$ http://www.ncbi.nlm.nih.gov/ 


\section{Preparation of Crude Actinobacteria extracts}

All isolates grew in $100 \mathrm{ml}$ of A1 medium with continuous shaking at $215 \mathrm{rpm}$ and $28^{\circ} \mathrm{C}$ for 8 days. At the end of the incubation period, amberlite resin XAD7 $\left(20 \mathrm{~g} \cdot \mathrm{l}^{-1}\right.$ of culture) was added and shaken for $2 \mathrm{~h}$ at $100 \mathrm{rpm}$. Subsequently, the culture was filtered and the resin was extracted by shaking in $100 \mathrm{ml}$ of acetone for $2 \mathrm{~h}$ at 100 rpm. Finally, the extract obtained was filtered and dried using reduced pressure distillation.

\section{СутотохіC ACTIVITY}

Each organic extract was tested against colorectal cancer cells HCT-116. The medium inhibitory concentration $\mathrm{IC}_{50}$ $\left(\mu \mathrm{g} \cdot \mathrm{ml}^{-1}\right)$ was calculated from the initial activity assay using a dilution method in a 96-well plate. As follows, 195 $\mu \mathrm{l}$ of colorectal cancer cells HCT-116 at $10 \mathrm{mg} \cdot \mathrm{ml}^{-1}$ final concentration in dimethyl sulfoxide (DMSO) were added to wells A1-A12, and $100 \mu$ lo the remaining wells. After that, $5 \mu \mathrm{l}$ of each organic extract was added to wells A1A10, $5 \mu \mathrm{l}$ of etoposide as a positive control to well A11 and $5 \mu \mathrm{l}$ of DMSO as a negative control to well A12. Subsequently, $100 \mu \mathrm{l}$ of each well from the first row was transferred to the second row, repeating this step until the end of the plate was reached while discarding the last $100 \mu \mathrm{l}$. After an incubation period of $72 \mathrm{~h}$, their absorbances were measured in a Plate Reader (Molecular Devices) at $490 \mathrm{~nm}$. For the IC determination, the first step was securing the \% of cell survival for every analyte and target, following this, the mortalities were corrected using Abbott's formula. With the mortalities corrected, the obtained information was introduced into the software BioStat 2008, through the Probit analysis to obtain the IC $_{50}$ values (STATPLUS 2008).

\section{FERMENTATION AND CHEMICAL ANALYSIS}

An inoculum from the AMT11 isolate was prepared in $100 \mathrm{ml}$ of A1 medium and cultured for 3 days at $215 \mathrm{rpm}$ and $28^{\circ} \mathrm{C}$. This inoculum was transferred to a $2.8 \mathrm{l}$ Fernbach flask containing 1 liter of the same medium. Following another eight days of incubation, amberlite resin XAD7 (20 g. $\mathrm{l}^{-1}$ of culture) was added and then shaken for $2 \mathrm{~h}$ at $100 \mathrm{rpm}$. The resin was filtered, washed with deionized water, and then the compounds were extracted using acetone. The acetone was removed using reduced pressure distillation. The crude extract was separated using a flash column with reverse phase silica gel C-18 following an elution gradient of water-methanol. All the fractions were tested to determine their cytotoxic activity. The $100 \%$ methanol fraction was then separated and purified using the high performance liquid chromatography (HPLC) in an Aquaflow Series II semipreparative chromatograph with a Waters R401 refractive index detector. A 1.0 x $25 \mathrm{~cm}$ Dynamax 60 A C-18 reverse phase column was utilized, with a methanol: ethyl acetate: acetonitrile (95:1:4) mix as eluent at a $2.0 \mathrm{ml} \cdot \mathrm{min}^{-1}$ flux. All the fractions obtained were analyzed in a liquid chromatography with mass detection (LC-MS) system, using a Hewlett-Packard MSD 1100 a C-18 RP column, and an acetonitrile gradient, ranging from $10 \%$ water to $100 \%$ acetonitrile. The fractions that showed characteristic masses of monactines or pamamycines were analyzed using high resolution mass spectrometry following the electrospray method (ESIMS) positive mode in a Thermo Scientific LTQ Orbitrap XL Spectrometer.

\section{Results}

Seven sediment samples were collected at different depths (15 and $32 \mathrm{~m}$ ) in different localities along the TSB (Fig. 1). Twenty six bacterial colonies with morphologic characteristics of actinomycetes were isolated, which is equivalent to 3.7 bacteria per sediment sample (Table 1). Seventy seven percent of the colonies showed a raised convex morphology, aerial hyphae, and a well-developed filamentous mycelium with spores that develop therein. It is interesting to point out that nine different colonial morphologies were observed in these samples; the mycelium colors observed were white, yellow, pink, red, orange, gray and black, and there is also a presence of colored exudates or agar pigmentation with yellow, red and black colors. Twenty three percent of the isolates showed colony morphology with no developed aerial hyphae and pigments ranging from light to dark orange, violet and brown.

Table 1. Marine sediment sampling sites, ocean depths, number of actinomycetes isolated and sequenced / Sitios de muestreo de sedimentos marinos, profundidad, número de actinomicetos aislados y secuenciados

\begin{tabular}{cccc}
\hline Site & Depth $(\mathrm{m})$ & Strains isolated & Sequenced \\
\hline 1 & 37 & 4 & 2 \\
2 & 19 & 2 & 1 \\
3 & 40 & 1 & 1 \\
4 & 19 & 6 & 2 \\
5 & 16 & 3 & 1 \\
6 & 25 & 1 & 1 \\
7 & 33 & 9 & 3 \\
\hline
\end{tabular}


The strains were divided into ten OTUs with 100\% sequence identities; one isolate from each OTU was used to construct the phylogenetic tree (Fig. 2). Six of those OTUs have never been reported (AMT1, AMT2, AMT4, AMT5, AMT6 and AMT20). Once the identity percentage decreased to $99 \%$, five OTUs were found to be related to actinomycete sequences previously isolated from soil, and two OTUs were related to known marine sequences. The partial 16S rRNA sequences (the used primers amplify the 16S gene at positions 27 and 1492, then the consensus sequences are the positions 388 to 1094 of Escherichia coli 16S) were analyzed, and their relation with 3 genera was determined. One of these OTUs was found for Micromonospora (2 isolates), one OTU for Nocardia (1 isolate), and five OTUs for the Streptomyces isolates ( $\mathrm{n}=$ 9) representing eighty two percent of the sequenced strains (Table 2).
Table 2. Number of Operational Taxonomic Units (OTUs) recovered from marine sediments calculated using consensus groups ranging from 98,99 and $100 \% 16 \mathrm{~S}$ rRNA gene sequence identity and total percentage shown in parentheses / Número de Unidades Taxonómicas Operacionales (UTOs) recuperadas de los sedimentos marinos, calculadas usando un consenso en grupos con 98,99 y $100 \%$ de identidad en la secuencia del gen $16 \mathrm{~S}$ rARN y porcentaje total de la muestra entre paréntesis

\begin{tabular}{lccc}
\hline & \multicolumn{3}{c}{$\%$ Sequence identity } \\
& $98 \%$ & $90 \%$ & $100 \%$ \\
\hline Not previously reported (new) & - & - & $6(60 \%)$ \\
Previously reported in soil & - & $5(71.4 \%)$ & $4(40 \%)$ \\
Known & $5(100 \%)$ & $2(28.6 \%)$ & - \\
Total & 5 & 7 & 10 \\
\hline
\end{tabular}

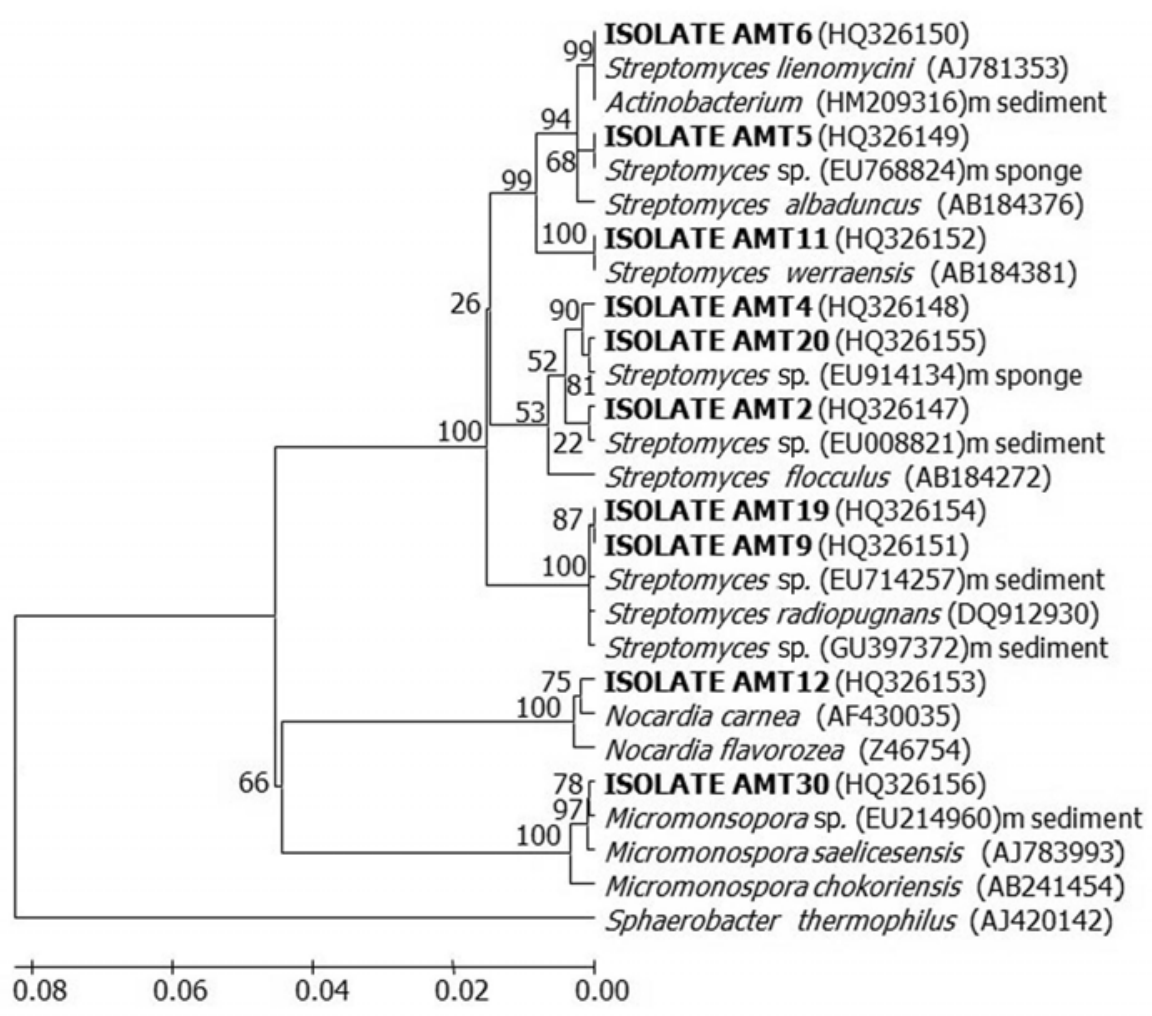

Figure 2. Phylogenetic tree based on 16S rRNA gene sequence analysis constructed using the Neighbor-joining method. Bootstrap values (in percent) calculated from 1,000 replicates shown at the nodes for values of $\leq 60 \%$. Sphaerobacter thermophilus were used to root the trees. Sequences from this study are shown in boldface and GenBank accession numbers are given between parentheses / Árbol filogenético basado en el análisis de las secuencias del gen 16S rARN construido usando el método del vecino más cercano. Los valores de arranque calculados de 1,000 (en porcentaje) son mostrados en los nodos para valores $\leq 60 \%$. Como raíz del árbol se usó Sphaerobacter thermophilus. Las secuencias de este estudio se representan en negritas y el número de acceso al GenBank está dado entre paréntesis 


\section{ACtinOBacterial Bioactivity}

Nineteen percent of the crude extracts obtained from the isolated strains from TSB showed activity against HCT-116 cancer cells; 50\% of the cancer cell inhibition was obtained at concentrations of 71.0, 69.0, 39.5, 13.9 and $\leq 0.076 \mu \mathrm{g} \cdot \mathrm{ml}^{-1}$ for the isolates AMT19, AMT2, AMT2, AMT18 and AMT11, respectively; according to 16S rRNA analysis, these isolates are related to the genus Streptomyces.

To find the compounds responsible for the activity observed, the most active strain AMT11 was grown in 8 $\mathrm{L}$ of medium A1. The crude extract was fractionated by reversed-phase column chromotography (C-18), and later, the fractions were purified by HPLC. The mass spectroscopy analysis of the fractions confirmed the presence of the monactin macrotetrolide $\left(\mathrm{C}_{41} \mathrm{H}_{66} \mathrm{O}_{12}\right)$ with a molecular ion of $\mathrm{m} / \mathrm{z}[\mathrm{M}]^{+} 750$ and a maximum absorbance wave length $\left(\lambda_{\max }\right)$ at $260 \mathrm{~nm}$, confirming the presence of this compound in the nonactines family (Fig. 3). Pamamycin-607 (PM-607) was identified at the maximum u.v. absorbance of $\lambda_{\max } 240 \mathrm{~nm}$, and the mass spectroscopy data showed a molecular ion of $\mathrm{m} / \mathrm{z} \quad[\mathrm{M}]^{+}$ 607 that agreed with the reported chemical structure for pamamycin-607, as well as an $\mathrm{m} / \mathrm{z} 213$ fragment found to correspond to the diol fraction of the molecule. These compounds showed an $\mathrm{IC}_{50}$ of $\leq 0.076 \mu \mathrm{g} \cdot \mathrm{ml}^{-1}$ activity against HCT-116 cancer cells.

\section{Discussion}

A raised convex morphology, aerial hyphae, and a welldeveloped filamentous mycelium with spores are common characteristics of the Streptomycetaceae family (Anderson \& Wellington 2001, Lo et al. 2002, Sujatha et al. 2005), shown in twenty sampled colonies However, six isolates showed morphological characteristics of the Micromonosporaceae family, these microorganisms had colony morphology with no developed aerial hyphae and pigments ranging from light to dark orange, violet and brown (Jensen et al. 1991, Mincer et al. 2002).

The indigenous state of Actinobacteria in the marine environment has been discussed since it has been hypothesized that actinomycetes spores were transported for many years from the terrestrial surface to the ocean, where they adapted physiologically becoming biologically active in the marine environment (Mincer et al. 2002). Unfortunately, the sediment pre-treatment (serial dilutions and plate stamping) could lead to the overestimation of the abundance of strains that are metabolically active in the marine environment as there is no distinction between actively growing strains and those that are in a latent state, as a spore or as another resistance structure that could have been transported to the coast. Nevertheless, this study did not recover strictly marinewater dependent Actinobacteria such as genus

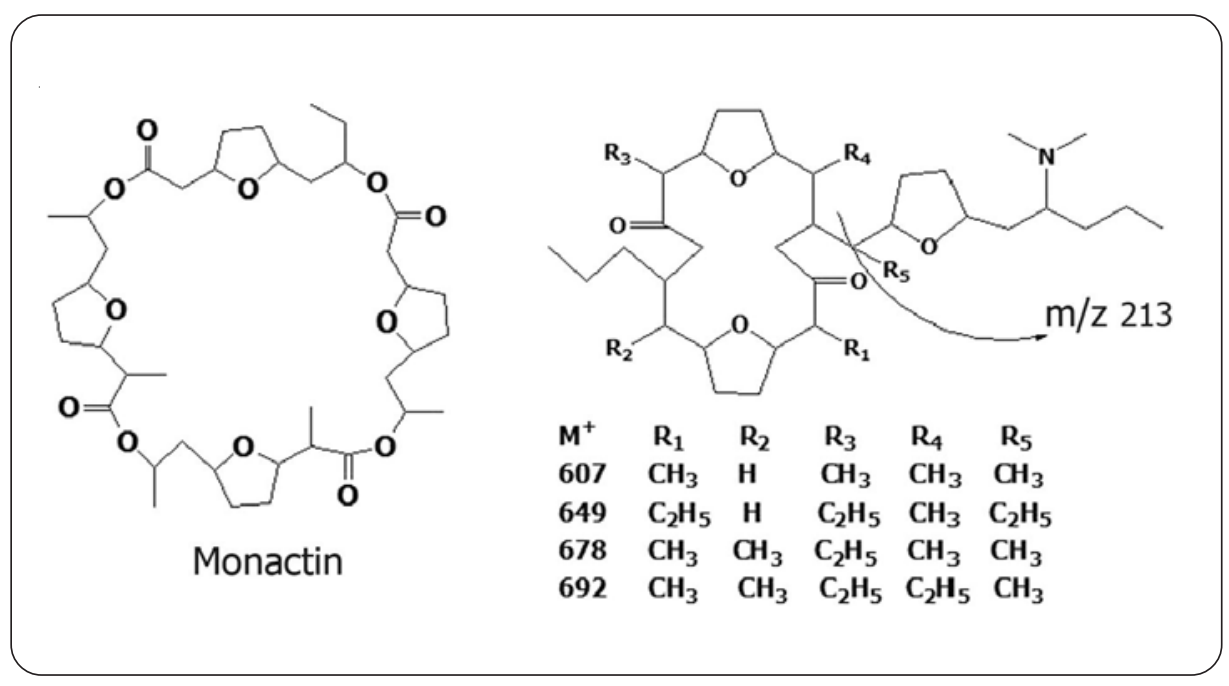

Figure 3. Chemical structure of the bioactive compounds monactin and pamamycines found in AMT isolate / Estructuras químicas de las compuestos bioactivos monactin y pamamycines encontrados en el aislado AMT11 
Salinispora (Maldonado et al. 2005) and all the isolated bacteria were able to grow in seawater and deionized water, which indicates that they are well adapted to live in saline environments. The abundance of isolates related to the genus Streptomyces were expected as previously reported for marine and terrestrial environments (Gontang et al. 2007). Particularly, the water in the coastal zone of TSB seems to be related to the California current system and its seasonal variation. The cold water in this area $\left(11^{\circ} \mathrm{C}\right)$ with a relative high salinity (33.7) is due to the emerging subsurface waters that result from the mixing process of subarctic water and equatorial Pacific water (Espinosa-Carreón et al. 2001). These conditions were present during the sampling period, and they could be responsible for the bacterial homogenization in the sea bottom. In addition the sediment transportation from the coastal zones and from Todos Santos islands converge on the central region of TSB (Sánchez et al. 2009) causing a circulation system between localities that results in a high percentage similitude between Actinobacteria from different collecting sites.

In this study the isolates that showed the highest bioactivity against HCT-116 cancer cells were related to the genus Streptomyces; this genus is abundant in marine coastal systems, where its abundance decreases far from the shore allowing the Actinobacteria diversity to increase (Jensen et al. 1991, Takizawa et al. 1993).

In the last decades, many studies have determined the anticancer activity of Actinobacteria isolated from marine environments. The percentage of bioactive strains observed in this study (19.2) was similar to the one reported by El-Shatoury et al. (2009) who found that the $17.5 \%$ of the isolated actinomycetes from marine environments showed antitumor activity. Hong et al. (2009) found that $20 \%$ of the bacteria isolated from different marine environments showed activity against colon cancer cells (HCT-116), and that the genus Streptomyces showed the highest activity in the in vitro assays.

The AMT11 isolate showed a high activity against the HCT-116 colorectal cancer cells. This strain shares 100\% 16S rRNA gene sequence identity with Streptomyces werraensis. This species has been previously reported in terrestrial environments and is the producer of several secondary metabolites (Rusanova et al. 2000). The compounds from the nonactines family found in this study, have been proved to have antibiotic and antitumor activity against different cell lines like mammalian erythroleukemia K562 (Bennett et al. 1962, Rrel et al. 1994) and have been isolated from different Streptomyces, including $S$. griseus of terrestrial and marine isolate origin (Bennett et al. 1962, Jois et al. 1986, Jeong et al. 2006). The Pamamycin-607 (PM-607) compound is characterized as having a macrolide ring of 16 members with a dimethylamine group in the lateral chain, which showed aerial mycelium inducing activity (Bernsmann et al. 2000, Kondo et al. 1988), and for presenting antibiotic activity. The molecular ions $m / z$ [M] $]^{+} 649,692$ and 678, previously isolated from S. albongier, were also detected and related with derivate compounds of the PM-607 (Kondo et al. 1988, Natsume et al. 1995), also the $m / z 213$ fragment found corresponding to the diol fraction of the molecule is considered as a sign structure of its fragmentation pattern (Natsume et al. 1995, Makoto et al. 2005).

Despite the growing interest in chemical biosynthesis, natural bioactive products from marine Actinobacteria are waiting to be discovered and developed. However, the development of new cultivation techniques is still a great challenge. Enriched and selective isolation methods can also be used to isolate rare Actinobacterias from marine ecological niches having the potential to biosynthesize novel bioactive compounds. These strains may have a great impact on human health and are a source of compounds with very promising antitumor activities.

\section{ACKNOWLEDGMENTS}

We thank the UABC for providing financial support through the XIII Internal Assembly, and we also thank the Consejo Nacional de Ciencia y Tecnología (Mexico) for the pre-doctorate fellowship given to A.B.E (number 5892). We are especially grateful to P. Jensen and W. Fenical for providing the support in the molecular and LC/MS analysis, and to H. Ocampo-Alvarez, E. García, and JL. Peña for their valuable help during the sampling trip aboard the ULLOA ship, and J.M. Domínguez for Figure 1. We also thank three referees for their helpful comments and suggestions.

\section{LITERATURE CITED}

Abbott WS. 1925. A method for computing the effectiveness of an insecticide. Journal of Economic Entomology 18: 2657.

Altschul SF, W Gish, W Miller, EW Myers \& DJ Lipman. 1990. Basic local alignment search tool. Journal of Molecular Biology 215: 403-410.

Anderson AS \& EMH Wellington. 2001. The taxonomy of Streptomyces and related genera. International Journal of Systematic and Evolutionary Microbiology 51: 797-814. 
Bennett RE, SA Brindle, NA Giuffre, PW Jackson, J Kowald, FE Pansy, D Perlman \& WH Trejo. 1962. Production of a novel cytotoxic agent, SQ 15,859, by Streptomyces chrysomallus. Antimicrobial Agents Chemotherapy 1: 169-172.

Bérdy J. 2005. Biactive microbiol metabolites. Journal of Antibiotics, Tokyo 58: 1-26.

Bernsmann H, B Hungerhoff, R Fechner, R Fröhlich \& $\mathbf{P}$ Metz. 2000. Toward the synthesis of pamamycin-607. Tetrahecron Letters 41: 1721-1724.

Cho JY, HC Kwon, PG Williams, CA Kauffman, PR Jensen \& W Fenical. 2006. Actinofuranones A and B, polyketides from a marine-merived bacterium related to the genus Streptomyces (actinomycetales). Journal of Natural Products 69: 425-428.

De la Lanza EG. 2004. Gran escenario de la zona costera y oceánica de México. Ciencias 76: 4-13.

El-Shatoury SA, NS El-Shenawy \& IMA El-Salam. 2009. Antimicrobial, antitumor and in vivo cytotoxicity of actinomycetes inhabiting marine shellfish. World Journal of Microbiology and Biotechnology 25: 1547-1555.

Ensign JC. 1978. Formation, properties, and germination of actinomycete spores. Annual Review of Microbiology 32: 185-219.

Espinosa-Carreón TL, G Gaxiola-Castro, JM RoblesPacheco \& S Nájera-Martinez. 2001. Temperature, salinity, nutrients and chlorophyll a in coastal waters of the southern California bight. Ciencias Marinas 27: 397422.

Feling RH, GO Buchanan, TJ Mincer, CA Kauffman, PR Jensen \& W Fenical. 2003. Salinosporamide A: a highly cytotoxic proteasome inhibitor from a novel microbial source, a marine bacterium of the new genus Salinospora. Angewandte Chemie International Edition 42: 355-357.

Fenical W, PR Jensen, MA Palladino, KS Lam, GK Lloyd \& BC Potts. 2009. Discovery and development of the anticancer agent salinosporamide A (NPI-0052). Bioorganic \& Medicinal Chemistry 17: 2175-2180.

Galkiewicz JP \& CA Kellogg. 2008. Cross-kingdom amplification using Bacterial-specific primers: Implications for coral microbial ecology. Applied of Environmental Microbiology 74: 7828-7831.

Gontang EA, W Fenical \& PR Jensen. 2007. Phylogenetic diversity of gram-positive bacteria cultured from marine sediments. Applied of Environmental Microbiology 73: 3272-3282.

Hall TA \& JW Brown. 2001. Theribonuclease P family. Methods Enzymology 341: 56-77.

Hardt IH, PR Jensen \& W Fenical. 2000. Neomarinone, and new cytotoxic marinone derivatives, produced by a marine filamentous bacterium (Actinomycetales). Tetrahedron Letters 41: 2073-2076.
Hong K, AH Gao, QY Xie, H Gao, L Zhuang, HP Lin, HP Yu, J Li, XS Yao, M Goodfellow \& JS Ruan. 2009. Actinomycetes for marine drug discovery isolated from mangrove soil and plants in China. Marine Drugs 7: 24-44.

Jensen PR \& C Mafnas. 2006. Biogeography of the marine actinomycete Salinispora. Environmental Microbiology 8: 1881-1888.

Jensen PR \& W Fenical. 2005. New natural-product diversity from marine actinomycetes. In: Zhang L \& AL Demain (eds). Natural products: drug discovery and therapeutic medicine, pp. 315-328. Humana Press, New Jersey.

Jensen PR, R Dwight \& W Fenical. 1991. Distribution of actinomycetes in near-shore tropical marine sediments. Applied of Environmental Microbiology 57: 1102-1108.

Jensen PR, PG Williams, DC Oh, L Zeigler \& W Fenical. 2007. Species-specific secondary metabolite production in marine actinomycetes of the genus Salinispora. Applied and Environmental Microbiology 73: 1146-1152.

Jeong SY, JH Shin, TK Kim, HS Lee, SK Park \& HM Kim. 2006. Streptokordin, a new cytotoxic compound of the methylpyridine class from a marine-derived Streptomyces sp. KORDI-3238. Journal of Antibiotics 59: 234-240.

Jois HRY, A Sarkar \& S Gurusiddaiah. 1986. Antifungal macrodiolide from Streptomyces sp. Antimicrobial agents and chemotherapy 30: 458-464.

Kondo S, K Yasui, M Natsume, M Katayama \& S Marumo. 1988. Isolation, physic-chemical properties and biological activity of pamamycin-607, an aerial mycelium-inducing substance from Streptomyces alboniger. Journal of Antibiotics 41: 1196-1204.

Kwon HC, CA Kauffman, PR Jensen \& W Fenical. 2006. Marinomycins A-D, antitumor-antibiotics of a new structure class from a marine actinomycete of the recently discovered genus 'Marinispora'. Journal of the American Chemical Society 128: 1622-1632.

Lo CW, NS Lai, HY Cheah, NKI Wong \& CC Ho. 2002. Actinomycetes isolated from soil samples from the Crocker Range Sabah. ASEAN Review of Biodiversity and Environmental Conservation [on line] <http:// http:// www.arbec.com.my/pdf/art21julysep02.pdf $>$.

Makoto H, K Haruhiko, K Ikuko, K Hiroshi, A Hiroshi \& N Masahiro. 2005. Biosynthetic origin of the carbon skeleton and nitrogen atom of panamycin-607, a nitrogen containing polyketide. Bioscience, Biotechnology and Biochemistry 69: 315-320.

Maldonado LA, W Fenical, PR Jensen, CA Kauffman, TJ Mincer, AT Bull, AC Ward \& M Goodfellow. 2005. Salinispora arenicola gen. nov., sp nov and Salinispora tropica sp nov., obligate marine actinomycetes belonging to the family Micromonosporaceae. International Journal of Systematic and Evolutionary Microbiology 55: 17591766. 
Marchesi JR, T Sato, AJ Weightman, TA Martin, JC Fry, SJ Hiom \& WG Wade. 1998. Design and evaluation of useful bacterium-specific PCR Primers that amplify genes coding for bacterial 16S rRNA. Applied and Enviromental Microbiology 64: 795-799.

Mincer TJ, PR Jensen, CA Kauffman \& W Fenical. 2002. Widespread and persistent populations of a major new marine Actinomycete Taxon in ocean sediments. Applied and Environmental Microbiology 68: 5005-5011.

Moore BS, JA Kalaitzis \& L Xiang. 2005. Exploiting marine actinomycete biosynthetic pathways for drug discovery. Antonie Van Leeuwenhoek 87: 49-57.

Natsume M, J Tazawa \& K Yagi. 1995. Structure-activity relationship of pamamycin: Effects of alkyl substituts. Journal of Antibiotics 48: 1159-1164.

Olano C, C Méndez \& JA Salas. 2009. Antitumor compounds from marine actinomycetes. Marine Drugs 7: 210-248.

Pathirana C, PR Jensen \& W Fenical. 1992. Marinone and debromomarinone: antibiotic sesquiterpenoid naphthoquinones of a new structure class from a marine bacterium. Tetrahedron Letters 33: 7663-7666.

Powers EM. 1995. Efficacy of the ryu nonstaining $\mathrm{KOH}$ technique for rapidly determining gram reactions of foodborne and waterborne bacteria and yeasts. Applied and Environmental Microbiology 61: 3756-3758.

Rrel MN, E Pereira, M Fiallo \& A Garnier-Suillerot. 1994. Mobile ionophores are a novel class of P-glycoprotein inhibitors. European Journal of Biochemistry 223: 125133.
Rusanova EP, TAAlekhova, GB Fedorova \& GS Katrukha. 2000. Development of a new method for synthesis of biologically active compounds with the use of the typed strain Streptomyces werraensis ATCC 1365. Applied Biochemistry and Microbiology 36: 266-270.

Sánchez A, J Carriquiry, J Barrera \& BE López-Ortiz. 2009. Comparación de modelos de transporte de sedimento en la Bahía Todos Santos, Baja California, México. Boletín de la Sociedad Geológica Mexicana 61: 13-24.

Soria-Mercado IE, A Prieto-Davo, PR Jensen \& W Fenical. 2005. Antibiotic terpenoid chloro-dihydroquinones from a new marine actinomycete. Journal of Natural Products 68: 904-910.

Staley J \& AK Ta. 1985. Measurement of in situ activities of nonphotosynthetic microorganisms in aquatic and terrestrial habitats. Annual Reviews in Microbiology 39: 321-346.

STATPLUS. 2008. Probit analysis. Biostat 2008. [on line] $<$ http://www.analystsoft.com.>

Sujatha P, KVVSN Bapi Raju \& T Ramana. 2005. Studies on a new marine Streptomycete BT-408 producing polyketide antibiotic SBR-22 effective against methicillin resistant Staphylococcus aureus. Microbiological Research 160: 119-126.

Takizawa M, R Colwell \& $\mathbf{R}$ Hill. 1993. Isolation and diversity of actinomycetes in the Chesapeake Bay. Applied and Environmental Microbiology 59: 997-1002.

Tamura K, J Dudley, M Nei \& S Kumar. 2007. MEGA4: Molecular Evolutionary Genetics Analysis (MEGA) software version 4.0. Molecular Biology and Evolution 24: 1596-1599.

Received 11 July 2011 and accepted 27 June 2012

Associated Editor: Gabriela Muñoz C. 